\title{
Review
}

\section{Bacterial pore-forming toxins: The (w)hole story?}

\author{
M. R. Gonzalez, M. Bischofberger, L. Pernot, F. G. van der Goot* and B. Frêche \\ Ecole Polytechnique Fédérale de Lausanne, Global Health Institute, Station 15, 1015 Lausanne (Switzerland), \\ Fax: +41-21-693-9538, e-mail: gisou.vandergoot@epfl.ch
}

Received 19 September 2007; received after revision 18 October 2007; accepted 23 October 2007

Online First 9 November 2007

\begin{abstract}
Pore-forming toxins (PFTs) are the most common class of bacterial protein toxins and constitute important bacterial virulence factors. The mode of action of PFT is starting to be better understood. In contrast, little is known about the cellular response to this threat. Recent studies reveal that cells do not just swell and lyse, but are able to sense and react to pore formation, mount a defense, even repair the damaged membrane and thus survive. These responses involve a
\end{abstract}

variety of signal-transduction pathways and sophisticated cellular mechanisms such as the pathway regulating lipid metabolism. In this review we discuss the different classes of bacterial PFTs and their modes of action, and provide examples of how the different bacteria use PFTs. Finally, we address the more recent field dealing with the eukaryotic cell response to PFTinduced damage.

Keywords. Pore-forming toxins, aerolysin, cholesterol-dependent cytolysin, cellular response, caspase-1.

\section{Introduction}

Pore-forming toxins (PFTs) represent the largest class of bacterial protein toxins and are often important virulence factors of a pathogen [1]. Forming pores in the membrane of target cells, which leads to cellular ion imbalance, is a widely used form of attack. Beside bacteria, many organisms as different as cnidarians, mushrooms and plants also produce PFTs [2-4]. Strikingly, even mammals utilize PFT-like proteins such as perforins as a part of their innate immune defense [5]. The fact that the use of pore formation is so widely spread suggests that PFTs evolved early in time and, therefore, represent an ancient form of attack. Until now, bacterial PFTs are the best described (for a review see $[1,6]$ ). They are secreted by the pathogens in a water-soluble form that binds to the target cell and generally multimerizes into an amphi- pathic structure that finally inserts in the target cell membrane and forms a pore (Fig. 1). This ability to convert from a soluble to a transmembrane form is common to all PFTs and constitutes one of their most remarkable features. In this review, we discuss the different classes of bacterial PFTs and their modes of action. We also provide a few examples of how the different bacteria use PFTs and then address the more recent field of eukaryotic cell responses to the damage induced by the PFTs. However, it should be noted already here that the knowledge about toxin-induced cellular phenomena lags behind our understanding of the structural mechanisms. This is probably because cell lysis was previously assumed to be the only cell fate after pore formation and, as such, the (w)hole story. Most probably it is just the beginning.

* Corresponding author. 


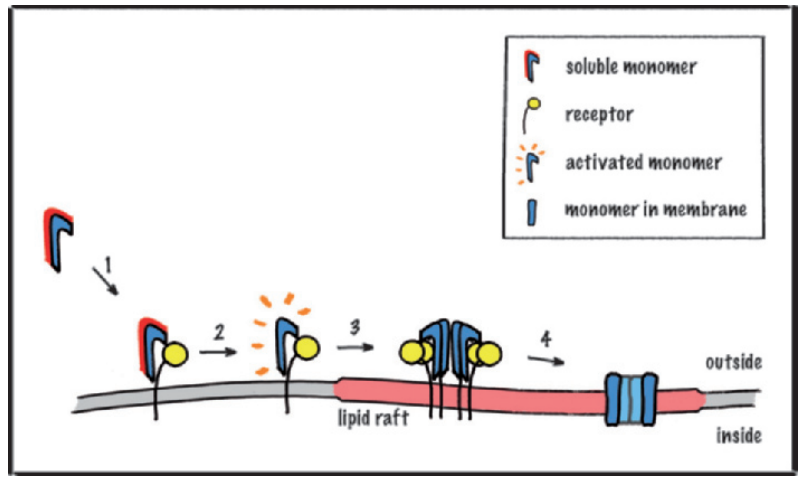

Figure 1. General mechanism of pore formation by $\beta$-pore-forming toxins (PFTs). Most PFTs are produced by the bacteria in form of soluble precursor toxins that diffuse towards the target cell and bind with high affinity through the interaction with a specific receptor (1). Some PFTs may then require activation by proteolytic cleavage (2). Common to all $\beta$-PFTs is the absolute requirement for oligomerization (3), a process that can be promoted by lipid rafts, into ring like structures that insert into the membrane and form pores (4).

\section{Classifications of PFTs}

PFTs are best classified according to the type of structures they use to insert into the lipid bilayer upon pore formation, i.e., $\alpha$-PFT cross the membrane as $\alpha$ helices and $\beta$-PFTs as $\beta$-sheets (Fig. 2). Pore-forming colicins secreted by Escherichia coli are representative members of the $\alpha$-PFTs family [7]. This family also includes the translocation domain of Diphtheria toxin [8], as well as the mammalian anti-apoptotic protein Bcl2 [9]. The pore-forming domains of multiple $\alpha$-PFTs such as colicins and Cry toxins from Bacillus thuringiensis have been crystallized in their water-soluble forms $[6,10-13]$. They all form a threelayered structure of up to ten $\alpha$-helices, which sandwich a hydrophobic helical hairpin. Partial unfolding of the protein, triggered by locally low $\mathrm{pH}$ and possibly other mechanisms, is thought to expose this central hydrophobic helical hairpin that then spontaneously inserts into the lipid bilayer [6]. Whereas partial unfolding might be sufficient to allow membrane insertion, channel formation most likely requires oligomerization of the protein. No definitive proof for multimerization is available for this class of toxins and thus the exact mechanism of pore formation remains unclear (Fig. 2a).

Formation of the transmembrane channel is much better understood for the $\beta$-PFT family. In contrast to $\alpha$-PFTs, sequence analysis predicts entirely soluble $\beta$ PFTs with no detectable hydrophobic stretches $[1,6]$. $\beta$-PFTs contain a high percentage of $\beta$-structure, and, in the early $90 \mathrm{~s}$, it was suggested that these toxins might cross lipid bilayers as $\beta$-barrels as observed for bacterial porins [14]. Studies on different toxins from this family have confirmed this hypothesis and led to the elucidation of an overall common mode of action. As all toxins, $\beta$-PFTs are synthesized as soluble proteins. At high concentration, they have the ability to multimerize into circular polymers, a step that for certain toxins, such as aerolysin, requires proteolytic activation $[15,16]$. Upon multimerization, each monomer contributes one (aerolysin from Aeromonas hydrophila and $\alpha$-toxin from Staphylococcus aureus) or 2 (cholesterol-dependent cytolysins [17]) amphipatic $\beta$-hairpins, which together generate an amphipathic $\beta$-barrel. This $\beta$-barrel exhibits a hydrophilic cavity and a hydrophobic outer surface thus allowing membrane insertion [17-20]. The number of monomers varies from 7 in the case of aerolysin and staphylococcal $\alpha$-toxin [21-23] to up to 50 in the case of the cholesterol-dependent cytolysins (CDC), which include streptolysin O (SLO) and perfringolysin O $[24,25]$. The pores formed by $\beta$-PFTs vary greatly in size, from $2 \mathrm{~nm}$ in diameter for aerolysin and $\alpha$-toxin, to $50 \mathrm{~nm}$ in diameter for CDC [6]. CDC pores can allow the passage of fully folded proteins and have, therefore, widely been used in cell biology to generate semi-permeabilized cell systems [26]. The difference in size between aerolysin- and CDC-type PFTs has a number of cellular consequences that are discussed below. It is presently not clear why different bacteria have evolved to produce toxins that generate pores of different sizes. The required cellular response during infection might provide the key to this interesting question.

A number of proteins that do not fully qualify as PFTs should also be mentioned briefly. Most prominent amongst these are the translocation domains of certain non-pore-forming toxins. These are the socalled $\mathrm{AB}$ toxins, where the $\mathrm{B}$ subunit is responsible for binding to the target cell and translocation of the A subunit into the cytoplasm. The A subunit bears the enzymatic activity. Examples include the already mentioned Diphtheria toxin, the translocation domain of which resembles colicins [27], and anthrax toxin, the B subunit of which forms a heptameric transmembrane channel reminiscent of the aerolysin and Staphylococcal $\alpha$-toxin channel [19, 28, 29]. In contrast to bona fide PFTs, B subunits of AB toxins do not insert into the plasma membrane of target cells because they require an acidic environment for membrane insertion to occur. Pore formation by B subunits only occurs in the endocytic pathway upon internalization [30-32].

Also related to PFTs are the tips of bacterial type III or type IV secretion systems (for review see [33]). Many pathogenic Gram-negative bacteria inject bacterial proteins into the host cell cytoplasm [34]. They do so by injecting proteins directly from their cyto- 


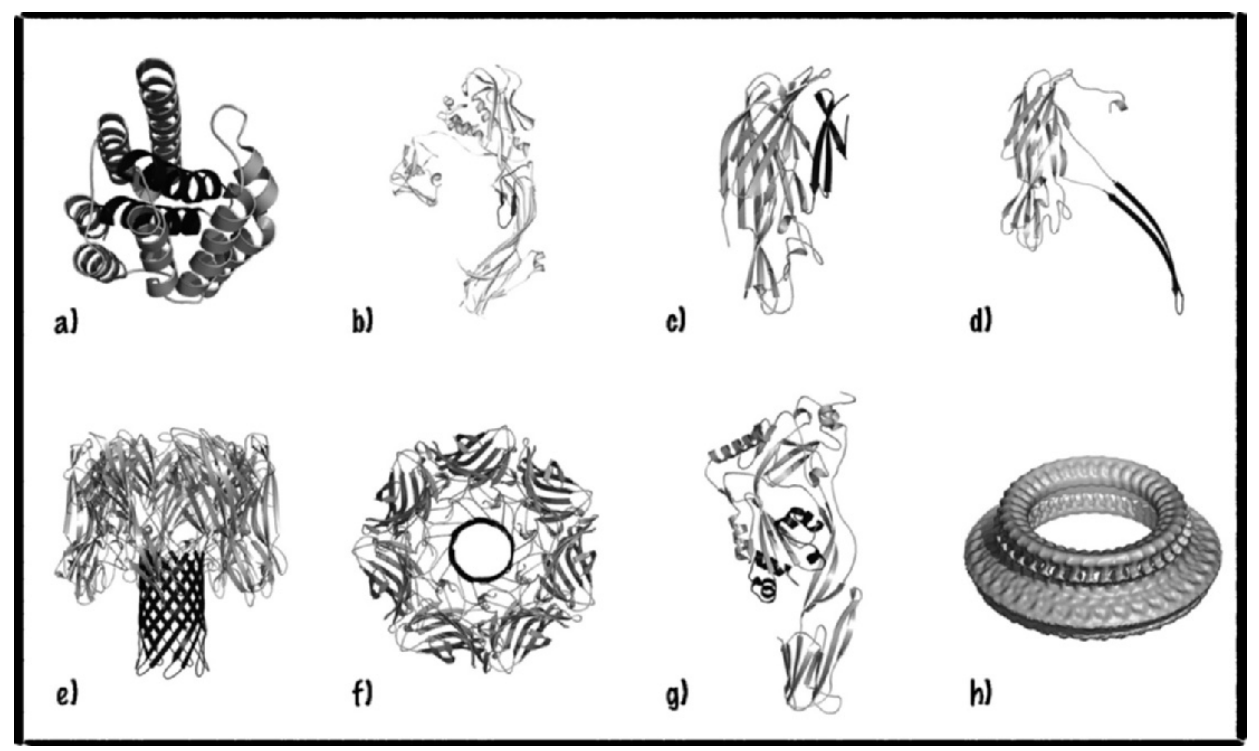

Figure 2. $\alpha$ - and $\beta$-PFTs. Ribbon representations of $\alpha$-and $\beta$-PFT structures. For each toxin, the region involved in forming the lipidspanning region of the pore is highlighted by dark shading. (a) $\alpha$-PFT family member colicin B secreted by Escherichia coli. (b) The structure of the water-soluble aerolysin by Aeromonas hydrophila. (c) The water-soluble LukF monomer. LukF is a PFT produced by Staphylococcus aureus and is thought to have a structure similar to that of the $\alpha$-toxin from the same organism. $(d) \beta$-PFT family member $\alpha$ toxin protomer, produced by $S$. aureus, as observed in the pore structure shown in $(e, f)$. $(e, f) S$. aureus $\alpha$-toxin heptameric pore viewed $(e)$ perpendicular to the pore axis, and $(f)$ down the axis [45]. $(g)$ Clostridium perfringens perfringolysin $\mathrm{O}$ as an example of a water-soluble CDC monomer. (h) Cryo-EM reconstruction of the Streptococcus pneumoniae pneumolysin pore [90]. Note the difference in monomer number and size between $(f)$ and $(h)$ (not same scale). All figures were produced by the computer program PyMol, except $(h)$ which was taken from [90].

plasm into that of the host cell through syringe-like structures called type III and IV secretion system. The type III secretion system (T3SS) is evolutionarily related to the flagellum and crosses both inner and outer bacterial membranes [35, 36]. It must also cross the host cell membrane and does so by producing proteins that have pore-forming ability. Examples include IpaB from Shigella flexneri, SipB from Salmonella sp. or YopB and YopD from Yersinia sp. [33]. Little is known about the structure by which these proteins cross the lipid bilayer. The high helical content and the presence of hydrophobic stretches indeed suggest an $\alpha$-helical transmembrane domain [37].

Here we focus on PFTs and proteins that affect mammalian cells, i.e., $\beta$-PFTs (since bona fide $\alpha$-PFTs such as colicins affect bacteria) and effectors of T3SSs.

\section{PFTs and their general mode of action}

Once secreted by the bacteria, PFTs diffuse towards their target cell, to which they bind via a specific receptor, often with high affinity [1]. The toxin thus hijacks cell surface structures, which are normally destined to other functions. Binding of the toxin to the cell surface is the first step in the intoxication process. If the receptor is not ubiquitous, this leads to cell-type-specific intoxication. In the absence of toxin-specific receptors, cells are indeed resistant to the action of the PFTs [38]. Receptors for a variety of PFTs have been identified (see Table 1 for a selection). These include transmembrane proteins, acting as receptors for the B subunit of AB toxins [39], lipidanchored proteins in the case of aerolysin [40], lipids for cholesterol-dependent cytolysins [41], and even specific lipid clusters proposed for Staphylococcal $\alpha$ toxin binding [42]. These receptors provide a number of advantages to the toxins. First, they provide binding sites to the cell surface. Lowering the diffusion space from three dimensions in the extracellular medium to two dimensions on the cell surface leads to a 1000-fold increase in concentration [43], which in turn increases the probability of monomer collision, a step essential in the oligomerization process, and thereby the efficiency of oligomerization. Further increase in local toxin concentration is obtained either because the receptor is pre-clustered or has a tendency to associate with specific membrane domains such as lipid rafts that are enriched both in glycosyl-phosphatidylinositol (GPI)-anchored proteins (the receptors for aerolysin) and cholesterol (the receptors for CDCs) [44].

As mentioned, oligomerization occurs in a circular fashion, leading to ring-like structures [45]. Certain toxins such as Staphylococcal $\alpha$-toxin initially form a 
Table 1. Bacterial pore-forming toxin (PFT) and related proteins.

\begin{tabular}{|c|c|c|c|c|}
\hline Toxin & Bacterium & Receptor & Toxin type & Reference \\
\hline Aerolysin & Aeromonas hydrophila & GPI-APs & Small $\beta$-PFT & {$[60]$} \\
\hline$\alpha$-toxin & Staphylococcus aureus & Lipid clusters & Small $\beta$-PFT & {$[42]$} \\
\hline$\alpha$-toxin & Clostridium septicum & GPI-APs & Small $\beta$-PFT & {$[59]$} \\
\hline Cry5B & Bacillus thurgiensis & GPI-APs, glycolipids, lipids & Small $\alpha$-PFT & [168] \\
\hline Streptolysin O (SLO) & Streptococcus pyogenes & Lipid/cholesterol & CDCs $(\beta$-PFT $)$ & [169] \\
\hline Listeriolysin O (LLO) & Listeria monocytogenes & Lipid/cholesterol & CDCs $(\beta$-PFT $)$ & {$[41]$} \\
\hline Pneumolysin O (PLY) & Streptococcus pneumoniae & Lipid/cholesterol & CDCs $(\beta$-PFT $)$ & {$[41]$} \\
\hline Perfringolysin O (PFO) & Clostridium perfringens & Lipid/cholesterol & CDCs $(\beta$-PFT $)$ & {$[41]$} \\
\hline Anthrax toxin & Bacillus anthracis & CMG2, TEM8 & AB/Small $\beta$-PFT & {$[96,97]$} \\
\hline Diphtheria toxin & Corynebacterium diphtheriae & HBEGF & $\mathrm{AB}$ & [170] \\
\hline Vcc & Vibrio cholerae & Carbohydrate receptors & Small $\beta$-PFT & [171] \\
\hline
\end{tabular}

pre-pore that undergoes a second series of conformational changes that lead to membrane insertion [46]. For others, such as aerolysin, oligomerization, folding of the transmembrane $\beta$-barrel and membrane insertion appear to be coupled events [18]. Exposure of the hydrophobic surface on the outside of the formed $\beta$ barrel is thought to provide the energy for membrane insertion, although no evidence is currently available to support this hypothesis.

\section{Toxins forming small pores: Aerolysin and related PFTs}

Aerolysin is one of the best-studied toxins from the category of small channel-forming toxins (reviewed in [47]). The toxin is produced by various species of the genus Aeromonas and is synthesized by the bacteria as a pre-protoxin. Pre-proaerolysin has a N-terminal signal sequence that directs it to translocate across the inner membrane of the bacteria [48]. In the periplasm of the bacteria, the toxin folds [49] and the precursor, proaerolysin, is then translocated into the extracellular medium through a type II secretion apparatus [50, 51]. After binding to GPI-anchored proteins at the target cell surface [40, 52-54], proaerolysin monomers are activated by proteolytic cleavage. However, activated aerolysin also readily binds to GPI-anchored proteins. Efficient proteolysis can be performed by proteases produced by the bacterium itself [16], enzymes of the digestive tract such as trypsin [16] or $\alpha$ chymotrypsin, or by cell surface-associated proteases, such as furin [15]. Activation, consisting of cleavage of the 40-amino acid C-terminal precursor peptide, is accompanied by a conformational change required for heptamerization and pore formation. Although the toxin may exist as a dimer in solution $[55,56]$, surface binding occurs in the monomeric state [57].
Aerolysin is L-shaped (Fig. 2b) with a small Nterminal lobe (domain 1) and a large lobe organized in three additional domains [58]. Domains 1 and 2 are involved in binding to the GPI-anchored receptors. Domain 2 binds to the glycan core of the GPI anchor [59] and domain 1 binds to N-linked sugar on the protein moiety $[60,61]$. This double binding leads to a high-affinity interaction of aerolysin with its receptor. Virtually all GPI-anchored proteins, which are generally highly glycosylated, can be used by aerolysin as a receptor, including Thy-1 [40], contactin [54], CD14, carboxypeptidase M or NCAM (neural cell-adhesion molecule) [62]. Notable exceptions are the prion protein (unpublished) and CD59 [60].

Domain 2 is also involved in initiating the oligomerization process [63], while domains 3 and 4 keep the heptamer assembled. The stability of this complex is reminiscent of that of prion aggregates, being resistant to boiling, detergents and high levels of chaotropic agents [64]. The membrane-spanning region corresponds to a $\sim 20$-amino acid loop that localizes to domain 3 (Fig. 2b), which folds into an amphipathic $\beta$ hairpin upon oligomerization and membrane insertion [18].

A homologue of aerolysin, $\alpha$-toxin, is produced by Clostridium septicum. It shares $27 \%$ sequence identity and $72 \%$ sequence similarity with aerolysin and is the main virulence factor of the bacterium [65]. As aerolysin, $\alpha$-toxin is secreted as an inactive protoxin, which is proteolytically activated by removal of a Cterminal peptide and binds to GPI-anchored membrane proteins [59]. The affinity for GPI-anchored proteins is, however, lower than aerolysin due to the fact that $\alpha$-toxin lacks the amino acid sequence corresponding to domain 1 of aerolysin, so that binding occurs only to the glycan core of the GPI anchor [61]. 
Another PFT forming small pores is $\alpha$-toxin from $S$. aureus. Studies on $\alpha$-toxin insertion showed that $\alpha$ toxin precursors bind to specific lipid clusters at the membrane of target cells [42]. Pore formation differs from that of aerolysin in that $\alpha$-toxin first forms a prepore [22, 66-69]. A conformational change then leads to the detachment of 3 small $\beta$-strands from the core of the protein (Fig. 2c) that unfold and refold to form a 14-stranded $\beta$-barrel with equivalent segments in the other protomers (Fig. 2e, f) [70-73].

Although the crystal structures of the water-soluble monomers of several small-pore-forming $\beta$-PFTs have been solved, only a single high resolution structure of the oligomer in a transmembrane state is available due to the difficulty of growing crystals of membrane proteins. The crystal structure of the $S$. aureus $\alpha$-toxin in its oligomeric form (Fig. 2e, f) [45] shows that the complex has a mushroom-like shape and measures approximately $10 \mathrm{~nm}$ in height and $10 \mathrm{~nm}$ in diameter. The structure revealed that seven $\beta$-hairpins associate together to form a 14-stranded antiparallel $\beta$-barrel that constitutes the transmembrane channel. Alternating polar and non-polar residues compose the transmembrane $\beta$-hairpin region. This structural element is also present in aerolysin [18], the B subunit of anthrax toxin, called protective antigen, [19] and $C$. septicum $\alpha$-toxin [20].

\section{Large-pore formers: The CDCs}

CDCs are around $60 \mathrm{kDa}$ in size and form the largest family of PFTs. As mentioned above, CDC pores can be formed by up to 50 monomers, each contributing $2 \beta$-hairpins to the transmembrane structure, thus leading to a 200 -stranded $\beta$-barrel, hence the classification of large-pore former CDCs (for a review see $[6,74])$. To date, the CDC family comprises over 20 members from 24 different Gram-positive bacterial species such as Clostridium, Streptococcus, Listeria or Bacillus [6, 74]. Interestingly, almost all CDC-producing bacteria are pathogenic for humans and/or animals. Most CDCs are produced extracellularly and insert into the plasma membrane of the target cell. This plasma membrane permeabilization may serve to affect the host cell (see below), or to transfer proteins secreted by the bacterium into the host cell as proposed for SLO from Streptococcus pyogenes [75]. Certain pathogens, such as Listeria monocytogenes, can produce their CDC both extracellularly [76] as well as after entry into the target cell by phagocytosis [77]. Insertion of this $\mathrm{CDC}$, termed listeriolysin $\mathrm{O}$ (LLO), into the phagosomal membrane allows the bacterium to escape into the cytoplasm of the target cell. Interestingly, of all CDCs, LLO is the only one that shows $\mathrm{pH}$ sensitivity [76], with a greatly increased pore-forming activity at low $\mathrm{pH}$ corresponding to the lumen of the phagosome. In contrast, activity is lower at the neutral $\mathrm{pH}$ corresponding to that of the extracellular space, as well as that of the host cell cytoplasm after bacterial release [76]. It can, however, not be excluded that LLO has additional roles when produced in the cytoplasm of the host cell.

At the level of the primary structure, CDCs display a high degree of sequence similarity ranging from $40 \%$ to $80 \%$ [6]. This is mainly reflected in the conserved core of about 471 amino acids shared by all CDCs, which essentially corresponds to the sequence of pneumolysin (PLY), the shortest member of the family [78]. CDCs with longer sequences usually display variations in the $\mathrm{N}$ terminus, the functions of which are unknown for many members. Furthermore, all CDCs contain a highly conserved undecapeptide, which is thought to be critical for cholesterol-mediated membrane recognition $[79,80]$. CDCs indeed all share a strict cholesterol dependency for oligomerization, which gave them their name. Most CDCs seem to use cholesterol directly as a receptor [81, 82]. Intermedilysin (ILY) from Streptococcus intermedius, however, was shown to have a proteinaceous receptor, i.e., the GPI-anchored protein CD59 [83]. Interestingly, ILY shows a lower degree of conservation in the conserved undecapeptide important for cholesterol binding [84]. As for all CDCs, pore formation by ILY requires the presence of cholesterol for the membrane insertion step [85]. The concentration and distribution of cholesterol in the membrane therefore probably plays a major role in the oligomerization process of CDCs and binding to cholesterol alone does not seem to be the full story [85]. Since microdomains (or lipid rafts) are also modulated by membrane cholesterol levels, it has been proposed that these lipid rafts further regulate CDC oligomerization [86, 87]. Vice versa, binding of CDCs to the membrane could stabilize or enlarge lipid rafts $[88,89]$ and trigger signaling events.

A recent electron microscopy reconstruction of PLY from Streptococcus pneumoniae nicely illustrates the hydrophobic pore complex (Fig. 2h), while Figure $2 \mathrm{~g}$ shows the $\mathrm{x}$-ray structure of the closely related perfringolysin $\mathrm{O}$ (PFO) monomer from Clostridium perfringens [90]. After membrane binding, oligomerization leads to a ring like structure termed the prepore. Membrane insertion occurs through a subsequent conformational change, the trigger for which might be the completion of the oligomerization process. During this transition, two $\alpha$-helical bundles in each monomer convert to a pair of amphiphatic $\beta$ hairpins that will ultimately line the pore $[17,41,90]$. There is still debate concerning the size of the 
channels that CDCs can make. Pores of up to $40 \mathrm{~nm}$ [90] diameters are generally admitted and in vitro experiments excluded the possibility of intermediate size pores by showing that PFO can form only large channels [91, 92]. However, intermediate arc-shaped oligomers, lined by protein on one side and by lipid on the other have been observed by cryo-electron microscopy and are thought to be functional $[93,94]$. Such structures, however, seem highly unfavorable in terms of energy and raise the possibility that the arc-like structures are a consequence of the preparation for electron microscopy. CDCs could also make smaller size pores, formed by fewer monomers.

\section{Channel formation by the anthrax toxin B subunit, or protective antigen}

Among the bacterial protein toxins, some members of the so-called AB toxins can be regarded as PFTs, such as diphtheria and anthrax toxins. The anthrax toxin from Bacillus anthracis is an AB toxin (for review see [95]), the B subunit of which shares many characteristics with $\beta$-PFTs. Anthrax toxin is composed of three independent polypeptide chains: the protective antigen (PA), the lethal factor (LF) and the edema factor (EF). Anthrax PA is secreted in a soluble form that has high affinity for two mammalian transmembrane proteins: tumor endothelial marker 8 (TEM8) and capillary morphogenesis gene 2 (CMG2) that act as its receptors $[96,97]$. Like proaerolysin, PA undergoes proteolytic activation at the cell surface via members of the furin family [98] and subsequent oligomerization into heptameric structures [30]. In contrast to aerolysin, pore formation does not occur at the cell surface, but only at the acidic $\mathrm{pH}$ of endosomes [31, 99]. Interestingly, the $\mathrm{pH}$ sensitivity is not dictated solely by the PA molecules but is provided by the interaction with the receptor $[100,101]$. Upon acidification, PA is thought to be partially released from the receptor [102], allowing the membrane-spanning region to unwind in each monomer and assemble together into a 14-stranded $\beta$-barrel [19].

The two enzymatic subunits have no surface receptors but interact with the PA heptamer and are coendocytosed with the complex, via clathrin-coated pits [103]. At acidic $\mathrm{pH}$, the PA heptamer inserts into the membrane $[99,104]$. Low $\mathrm{pH}$ also triggers partial unfolding of EF and LF, which can then cross the membrane through the PA channel $[105,106]$. Interestingly, the PA channel was found to form not in the limiting membrane of endosomes, but rather in the intraluminal vesicles of this multivesicular organelle [31]. Release into the cytoplasm of the enzymatic subunits, therefore, requires back fusion of these intraluminal vesicles with the limiting membrane of the organelle. Little is known about this back fusion process, which could be promoted by the PA channel. The anthrax toxin is, therefore, an interesting example of a combination between a PFT structure and enzymatically active proteins.

\section{Type III secretion systems}

Another bacterial virulence factor that represents some similarities with PFTs is the T3SS, which is produced by many Gram-negative bacteria. This secretion machinery allows bacteria to modulate eukaryotic cells by injecting proteins directly into their cytosol (for review see [33]). The T3SS has been well characterized in bacteria like Shigella, Yersinia or Salmonella and is thought to be derived from the bacterial flagellum due to structural similarities [3436]. The T3SS injection system is found in both pathogenic and symbiotic bacteria. It is composed of an injectisome, which represents a needle-like structure and a translocator, which forms a pore in the membrane of the target cell allowing the transport of proteins directly into the eukaryotic cell. These proteins, called effectors, are able to interfere with the normal control and signaling of the target cell. IcsB, for example, is secreted by the invasive bacteria Shigella flexneri, and allows the bacteria to escape from the cellular autophagic pathway by preventing bacterial recognition by the cell [107]. Other effectors have been shown to act on the actin cytoskeleton by modulating phagocytosis through induction [76] or inhibition $[34,108]$ of bacterial uptake. Additionally, some effectors have also been shown to modulate vesicular trafficking once the bacterium has been internalized [109]. It has also been reported that some of them modulate the innate and adaptive immune response $[110,111]$.

\section{Role of PFTs in pathogenesis}

Although it has been clearly established for a variety of bacterial pathogens that their PFT(s) contribute and are sometimes essential for pathogenesis, the exact role of PFTs is not always clear. It is also noteworthy that the events triggered by pore formation in the plasma membrane of a target cell vary depending on toxin concentration, exposure time to the toxin, as well as target cell type (Fig. 3). Toxin concentrations during infection have, however, not been established and are likely to vary depending of the site of infection and the distance between the target cell and the producing bacterium. 


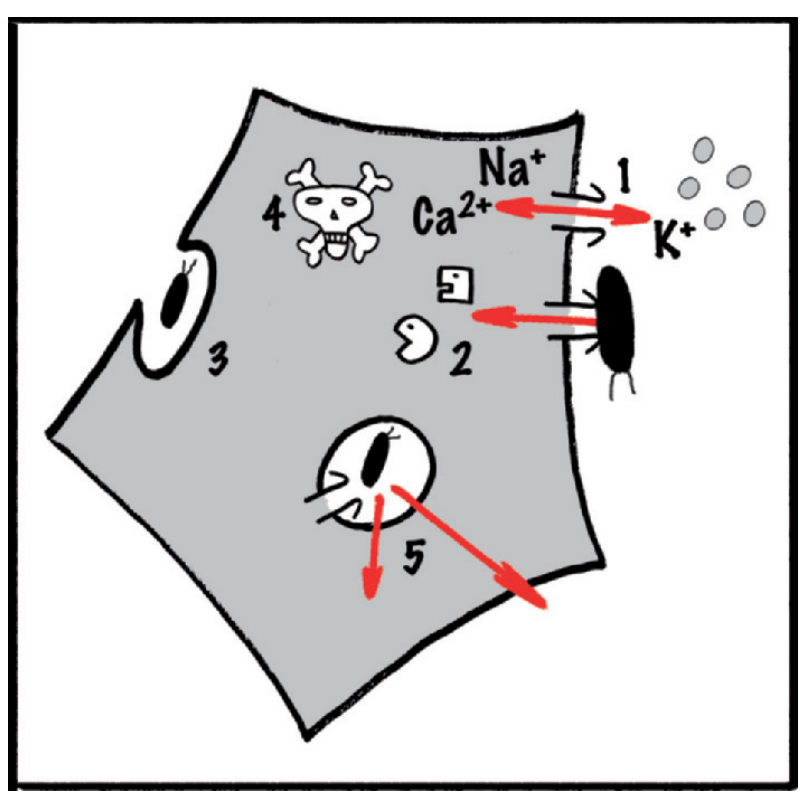

Figure 3. Induced cellular effects of PFTs. One effect of pore formation at the plasma membrane is the permeabilization of the plasma membrane to ions leading to changes in cytoplasmic ion composition and the release of nutrients (1). The large pores formed by members of the CDC also allow the efflux of intracellular proteins (1). Bacteria can also directly inject proteins, termed effectors, into the target cell cytoplasm via type III or type IV secretion machineries (2). These bacterial proteins are able to modify specific cellular mechanisms for the benefit of the bacterium, e.g., inducing phagocytosis of the bacterium (3). All these effects of bacterial toxins and effectors may eventually lead to the death of the host cell (4). Pore formation can also occur after the bacterium has been internalized. This allows, for example, escape of the bacterium from the phagosome into the cytosol, where it can replicate, or egress of the bacterium outside the cell once replication in the target cell has occurred (5).

One of the clearest absolute requirement for a PFT during infection is that of Listeria for LLO. This toxin mediates escape of the bacterium into the cytoplasm, thus preventing phagosome maturation and killing of the bacterium in phagolysosomes [112]. LLO, however, appears to contribute to pathogenesis in a variety of other fashions. Pore formation of LLO at the cell surface generates calcium-dependent and lipid-mediated signaling, leading to a variety of events such as tyrosine phosphorylation events [89], actin rearrangement [113], NF- $\kappa B$ activation [114] and regulation of gene expression through histone modification [115]. LLO was also found to induce calcium influx or, in certain cases, even oscillations [116]. These oscillations were also observed in the case of E. coli $\alpha$ hemolysin (HlyA) [117, 118]. Calcium puffs and spikes are known to be complex mechanisms that modulate transcriptional regulation in an intensityand frequency-dependent manner [119, 120]. The LLO-induced calcium waves have been shown to regulate different cellular functions such as bacterial internalization, endocytic vesicle fusion, degranula- tion, cytokine synthesis and apoptosis [121, 122]. Activation of similar intracellular events has been reported for other PFTs, such as actin rearrangement or NF- $\kappa \mathrm{B}$ activation by PLY [123].

The importance of PFTs during infection has also been clearly established for PLY [124], produced by all serotypes of Streptococcus pneumoniae [125-127] and is essential for virulence. PLY contributes to the pathogenesis of various pneumococcal disease syndromes in a number of ways (for review see [128]). PLY has several distinct functions, especially in the early pathogenesis of pneumococcal infection. The enzyme is cytotoxic to ciliated bronchial epithelial cells and disrupts tight junctions and the integrity of the bronchial epithelial monolayer [129, 130]. In addition, PLY action disrupts the alveolar-capillary boundary favoring the spread of the bacteria into the pulmonary interstitium and ultimately into the bloodstream [128]. The cytotoxic effects of PLY can directly inhibit phagocyte and immune cell function, which leads to suppression of the host inflammatory and immune responses [128].

Another situation where PFT requirement has been put forward is that of the delivery by Streptococcus of bacterial NAD-glycohydrolase into the eukaryotic target cell cytoplasm. Translocation was shown to occur via the SLO pore by a polarized process [75]. The authors describe that SLO, the CDC of the Grampositive pathogen S. pyogenes, directs the translocation of a streptococcal effector molecule into the host cell cytosol. Furthermore, the effector, which is capable of producing the potent eukaryotic second messenger molecule cyclic ADP-ribose, contributes to a cytotoxic response in keratinocytes during infection by $S$. pyogenes [45]. These data provide a novel function for the large family of CDCs and suggest that toxin-mediated translocation may be a general mechanism for injection of effectors and, thus, serve as the functional equivalent of T3SSs for Gram-positive pathogens.

\section{Sensing bacterial toxins: The Nod-like receptors}

Considering that pore-formation constitutes a very ancient form of attack that resembles mechanical membrane rupture, it is likely that cells have evolved mechanisms to resist and/or repair this kind of damage. This implies that cells have means to sense impairment of their plasma membrane, one of the first consequences of which is changes in ionic composition (Fig. 4).

The innate immune system provides a first line of host cell defense against many microorganisms including bacteria. The cells of the innate immune system, 


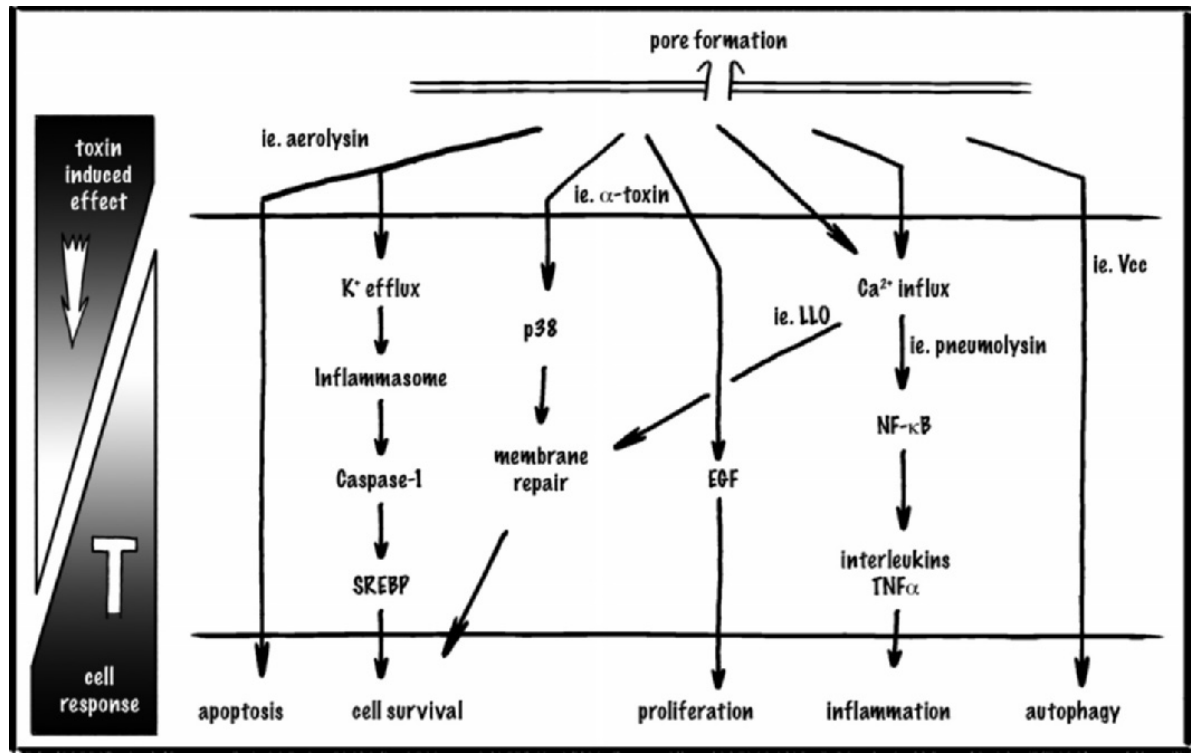

Figure 4. Cellular responses induced by PFTs. Several pathways activated in the host cell by PFTs are depicted. EGF, epidermal growth factor; SREBP, sterol responsive element binding protein; LLO, listeriolysin O; SLO, streptolysin $\mathrm{O}$.

usually include macrophages and neutrophils but also epithelial cells, which constitute the first physical barrier to pathogens. Unlike adaptive immunity, the innate immune system is a nonspecific immune response based on a much smaller number of receptors called pattern recognition receptors (PRRs). These receptors are microbial sensing proteins that recognize conserved structural components of the microorganisms, called pathogen-associated molecular patterns (PAMPs) [131]. Bacterial cell wall components such as peptidoglycan, bacterial flagellin, and nucleic acid structures, unique to bacteria and viruses, are examples of PAMPs.

The first family of PRRs studied in detail was the Tolllike receptor (TLR) family [132]. TLRs are transmembrane proteins with a ligand-binding domain composed of leucine-rich repeats (LRRs). They are involved in the detection of microbes in the extracellular compartment and in endosomes. More recently, another family of PAMP detectors has been discovered, which in analogy to the TLRs have been termed NLRs or Nod-like receptors [133]. In contrast to the TLRs, they reside in the cytoplasm and have been shown to be activated upon treatment with several PFTs [134, 135]. The NLRs comprise two large sub-classes, the NODs (NOD1-5) and the NALPs (NALP1-14), that have ligand-binding domains composed of LRRs. Upon ligand binding they form large multiprotein complexes allowing interactions with downstream effectors and/or adaptor proteins. The two major documented downstream effects of NLR activation are $\mathrm{NF}-\kappa \mathrm{B}$ and caspase- 1 activation, events that involve different NLR members [136].

$\mathrm{NF}-\kappa \mathrm{B}$, a heterodimeric transcription factor, is a key regulator of the pro-inflammatory response, activat- ing genes that encode cytokines and co-stimulatory factors [137]. Interleukin (IL)- 8 production, as a consequence of the activation of the $\mathrm{NF}-\kappa \mathrm{B}$ pathway, was observed upon treatment with Staphylococcal $\alpha$ toxin [138], aerolysin [139], PLY [140] and LLO [141]. The multiprotein complexes involved in caspase-1 activation have been termed, by Tschopp and coworkers, the inflammasome [142]. Caspase-1 is responsible for the processing and activation of the proinflammatory cytokines IL-1 $\beta$ and IL-18 [143]. Among the toxins forming small pores, $\alpha$-toxin from S. aureus and aerolysin from $A$. hydrophila have been shown to activate the inflammasome [134, 135]. In this case, the trigger of inflammasome activation is potassium efflux through the toxin pore. LLO produced by L. monocytogenes also results in caspase- 1 activation and subsequent IL-1 $\beta$ secretion $[144,145]$. It is, however, not clear at what step LLO pore formation is involved in caspase- 1 activation: pore formation in the plasma membrane or in the phagosome? Is cytoplasmic release of the bacterium the required event? In other words, is inflammasome assembly triggered by changes in ion composition or by the presence of the bacteria inside the cytoplasm?

Another toxin to which cells seem to respond in an inflammasome-dependent manner is the anthrax toxin. Macrophages treated with anthrax lethal toxin were found to secrete IL-1 $\beta$ and IL-18 after caspase-1 activation [146, 147]. The mechanisms leading to inflammasome activation in response to lethal toxin are still unclear. However, it is unlikely that the LF itself is recognized by intracellular PRRs, since a catalytically inactive LF was unable to trigger caspase1 activation, despite its delivery to the cytoplasm (Reig, Mellman and van der Goot, submitted). It has 
recently been proposed that caspase- 1 activation by anthrax toxin depends on the release of intracellular potassium and on the proteasome [148].

Inflammasome activation has also been described upon host cell invasion by type III or type IV secretion harboring bacteria. In these instances, the responsible PAMP was, however, found to be flagellin [136, 149151]. At present, recognition of bacterial effectors has not been reported. A recent work, however, highlights the importance of membrane impairment induced by the injection needle, suggesting that as for PFTs making small pores, potassium efflux could contribute to inflammasome activation [152].

A consequence of inflammasome activation by PFTs is the processing of proinflammatory cytokines. More recently described is the activation of the central regulators of lipid metabolism, the sterol responsive element binding proteins (SREBPs) [134]. These are membrane-bound transcription factors that control the synthesis of enzymes involved in lipid metabolism [153]. Caspase-1-mediated SREBP activation was, furthermore, found to promote cell survival after toxin attack revealing a mechanism by which the cells seem to react to the damage induced by PFTs.

\section{Other pathways induced by PFTs: P38 MAPK and autophagy}

Among the signaling pathways induced by PFTs, some promote cell survival (Fig. 4). The p38 mitogenactivated protein kinase (MAPK) pathway has been shown to be essential to respond to toxin injury in both nematodes and mammalians and was the first one to be described in promoting cell survival. Huffman et al. [154] showed that transcription of p38 was up-regulated in Caenorhabditis elegans treated with the Crystal toxin Cry5B produced by $B$. thuringiensis, and that blocking downstream targets of p38 using siRNA produced animals hypersensitive to toxin injury. These results are in agreement with a preview study that showed enhanced $C$. elegans susceptibility to bacterial pathogens when the p38 homolog pmk-1 was knocked-down [155]. The p38 pathway was also found to be involved in the cellular response of Baby Hamster Kidney cells to aerolysin, since p38 inhibitors led to an increase in toxin-induced cell death [154]. Activation of p38 was also observed upon exposure of epithelial cells to other PFTs like PLY, SLO, $S$. aureus $\alpha$-toxin and anthrolysin from $B$. anthracis [156-159]. Interestingly, activation of p38 was dependent on osmotic stress induced by pore formation, as it could be prevented by the addition of high molecular weight dextran to the extracellular medium [157]. Further- more, p38 was shown to contribute to membrane resealing after exposure to Staphylococcal $\alpha$-toxin, and the p38 pathway was protective to the cells [156]. These results did not extend to SLO treatment [156]. In contrast, upon exposure to the large PFT PLY, p38 was found to mediate neuronal cell death [159]. Thus, p38 activation seems to be a conserved feature of cells responding to a pore; however, the effects of p38 activation might differ from one toxin to the other, possibly related to the size and stability of the formed pore and/or the type of target cell.

In addition to the p38 pathways, PFTs might lead to the activation of other MAPK pathways such as the observed activation of c-Jun N-terminal kinase (JNK) by SLO, leading to TNF- $\alpha$ production [158].

Interestingly, pore formation by Staphylococcal $\alpha$ toxin was found to trigger cell proliferation through the activation of epidermal growth factor receptor (EGFR) and its crucial adaptor protein Shc [160]. This activation leads to an increase in cell proliferation, to an extend similar to that of treatment with the epidermal growth factor HB-EGF. The mitogenic effect was also induced in cells treated with SLO and seems to be dependent on the hole-forming activity of the toxin, since an inactive Staphylococcal $\alpha$-toxin mutant did not induce proliferation.

Autophagy has also been reported to be a cellular defense induced upon pore formation by a cytolysin from Vibrio cholerae (Vcc) [161]. This PFT has been shown to induce vacuolation and autophagy in target cells. Strikingly, inhibition of autophagosome formation by RNAi or drugs resulted in decreased cell survival upon Vcc intoxication. The invasive bacteria S. flexneri as a whole is also known to be targeted by the cell's autophagic machinery, but, as mentioned, escapes it by injecting a specific effector called IcsB into the cytoplasm via a T3SS [107]. The innate defense role of autophagy against other bacterial pathogens has also been demonstrated with $S$. pyogenes and M. tuberculosis [162, 163]. Recently, autophagy has also been suggested to protect Shigella-invaded macrophages, since inhibition of autophagy promoted cell death [164]. Interestingly, caspase-1 seems to inhibit autophagy in this setup, while the adaptor protein ASC positively regulates autophagosome maturation. Autophagy, usually known for degradation of organelles, can therefore act as a specific cellular response during infection with certain pathogens and even upon intoxication with purified PFTs and, thereby, promote cell survival. 


\section{Membrane repair}

After membrane disruption by a PFT, some cell types have been shown to undergo a recovery process in terms of potassium and ATP levels leading to a prolonged survival. This recovery mechanism has been described for $S$. aureus $\alpha$-toxin injuries of fibroblasts and also involves p38 [165]. Cells treated with LLO and SLO are also able to repair their lesions, but with distinctly different time scales. While membrane damage induced by large CDC pores is repaired in less than $1 \mathrm{~h}$, cells treated with small-pore formers need many hours to regain normal intracellular potassium levels [26]. Furthermore, it seems that the resealing mechanism after SLO membrane permeabilization does not depend on p38, but on calcium [156]. Calcium influx is generally accepted to be important for membrane repair in physically injured cells, where fusion of intracellular organelles with the plasma membrane constitutes part of the repair mechanism [166]. Plasma membrane repair, therefore, seems to be the most obvious candidate process of a cell's defense, since the main problem is indeed a hole in the membrane. The difference in time scale between the repair of CDC-induced damage $(<1 \mathrm{~h})$ and that of Staphylococcal $\alpha$-toxin induced damage (hours) suggest that different repair mechanisms are involved, the former being calcium dependent and the later p38 dependent. One important differentiating factor could be the stability of the pores, although there is currently no evidence for this. It indeed appears that Staphylococcal $\alpha$-toxin and even more so aerolysin oligomers are far more stable [167] than those formed by CDCs.

The recently reported link between the activation of the SREBP pathway [134] upon treatment with aerolysin also suggests a role for lipogenic genes in cell survival. An alternative possibility has been suggested for cell recovery following exposure to Staphylococcal $\alpha$-toxin, which is closure of the pore via constriction of the transmembrane $\beta$-barrel [165]. Clearly further studies are required to understand the mechanisms leading to cell survival following attack by small-pore-forming PFTs.

\section{Concluding remarks}

Majors advance have been made over the last decade in the understanding of the structure and poreformation mechanisms of PFTs. In contrast, little is known still about the consequences of pore formation at the cellular level. Ion imbalance such as increase in cytosolic calcium and decrease in intracellular potassium appear to be sensed by cells, leading to a variety of signaling cascades, some of which are starting to be elucidated. Pore formation is, however, a major threat for cells and it appears that this stress leads to a great variety of signaling pathways that need to be identified and elucidated.

Acknowledgements. This work was supported by a grant from the Swiss National Science Foundation. B.F. is a recipient of a fellowship from the Fondation pour la Recherche Médicale. G.v.d.G is an international Fellow of the Howard Hughes Medical Institute.

1 Van der Goot, F. G. E. (2001) Pore Forming Toxins. Springer Verlag, Berlin.

2 Sher, D., Fishman, Y., Zhang, M., Lebendiker, M., Gaathon, A., Mancheno, J. M. and Zlotkin, E. (2005) Hydralysins, a new category of beta-pore-forming toxins in cnidaria. J. Biol. Chem. 280, 22847-22855.

3 Sousa, M. V., Richardson, M., Fontes, W. and Morhy, L. (1994) Homology between the seed cytolysin enterolobin and bacterial aerolysins. J. Protein Chem. 13, 659-667.

4 Mancheno, J. M., Tateno, H., Goldstein, I. J., MartinezRipoll, M. and Hermoso, J. A. (2005) Structural analysis of the Laetiporus sulphureus hemolytic pore-forming lectin in complex with sugars. J. Biol. Chem. 280, 17251-17259.

5 Pipkin, M. E. and Lieberman, J. (2007) Delivering the kiss of death: Progress on understanding how perforin works. Curr. Opin. Immunol. 19, 301-308.

6 Parker, M. W. and Feil, S. C. (2005) Pore-forming protein toxins: From structure to function. Prog. Biophys. Mol. Biol. 88, 91-142.

7 Lakey, J. H. and Slatin, S. L. (2001) Pore-forming colicins and their relatives. Curr. Top. Microbiol. Immunol. 257, 131-161.

8 Collier, R. J. (2001) Understanding the mode of action of diphtheria toxin: A perspective on progress during the 20th century. Toxicon 39, 1793-1803.

9 Schendel, S. L., Xie, Z., Montal, M. O., Matsuyama, S., Montal, M. and Reed, J. C. (1997) Channel formation by antiapoptotic protein Bcl-2. Proc. Natl. Acad. Sci. USA 94, $5113-5118$

10 Wiener, M., Freymann, D., Ghosh, P. and Stroud, R. M. (1997) Crystal structure of colicin Ia. Nature 385, 461-464.

11 Hilsenbeck, J. L., Park, H., Chen, G., Youn, B., Postle, K. and Kang, C. (2004) Crystal structure of the cytotoxic bacterial protein colicin B at 2.5 Å resolution. Mol. Microbiol. 51, 711720.

12 Vetter, I. R., Parker, M. W., Tucker, A. D., Lakey, J. H., Pattus, F. and Tsernoglou, D. (1998) Crystal structure of a colicin $\mathrm{N}$ fragment suggests a model for toxicity. Structure 6, $863-874$.

13 Galitsky, N., Cody, V., Wojtczak, A., Ghosh, D., Luft, J. R., Pangborn, W. and English, L. (2001) Structure of the insecticidal bacterial delta-endotoxin Cry3Bb1 of Bacillus thuringiensis. Acta Crystallogr. D Biol. Crystallogr. 57, $1101-$ 1109.

14 Schulz, G. E. (2002) The structure of bacterial outer membrane proteins. Biochim. Biophys. Acta 1565, 308-317.

15 Abrami, L., Fivaz, M., Decroly, E., Seidah, N. G., Jean, F., Thomas, G., Leppla, S. H., Buckley, J. T. and van der Goot, F. G. (1998) The pore-forming toxin proaerolysin is activated by furin. J. Biol. Chem. 273, 32656-32661.

16 Howard, S. P. and Buckley, J. T. (1985) Activation of the holeforming toxin aerolysin by extracellular processing. J. Bacteriol. $163,336-340$.

17 Shatursky, O., Heuck, A. P., Shepard, L. A., Rossjohn, J., Parker, M. W., Johnson, A. E. and Tweten, R. K. (1999) The mechanism of membrane insertion for a cholesterol-dependent cytolysin: A novel paradigm for pore-forming toxins. Cell 99, 293-299. 
18 Iacovache, I., Paumard, P., Scheib, H., Lesieur, C., Sakai, N., Matile, S., Parker, M. W. and van der Goot, F. G. (2006) A rivet model for channel formation by aerolysin-like poreforming toxins. EMBO J. 25, 457-466.

19 Nassi, S., Collier, R. J. and Finkelstein, A. (2002) PA63 channel of anthrax toxin: An extended beta-barrel. Biochemistry $41,1445-1450$.

20 Melton, J. A., Parker, M. W., Rossjohn, J., Buckley, J. T. and Tweten, R. K. (2004) The identification and structure of the membrane-spanning domain of the Clostridium septicum alpha toxin. J. Biol. Chem. 279, 14315-14322.

21 Moniatte, M., van der Goot, F. G., Buckley, J. T., Pattus, F. and van Dorsselaer, A. (1996) Characterisation of the heptameric pore-forming complex of the Aeromonas toxin aerolysin using MALDI-TOF mass spectrometry. FEBS Lett. 384, 269-272.

22 Valeva, A., Palmer, M. and Bhakdi, S. (1997) Staphylococcal alpha-toxin: Formation of the heptameric pore is partially cooperative and proceeds through multiple intermediate stages. Biochemistry 36, 13298-13304.

23 Wilmsen, H. U., Leonard, K. R., Tichelaar, W., Buckley, J. T. and Pattus, F. (1992) The aerolysin membrane channel is formed by heptamerization of the monomer. EMBO J. 11, 2457-2463.

24 Olofsson, A., Hebert, H. and Thelestam, M. (1993) The projection structure of perfringolysin $\mathrm{O}$ (Clostridium perfringens theta-toxin). FEBS Lett. 319, 125-127.

25 Sekiya, K., Satoh, R., Danbara, H. and Futaesaku, Y. (1993) A ring-shaped structure with a crown formed by streptolysin $\mathrm{O}$ on the erythrocyte membrane. J. Bacteriol. 175, 59535961

26 Walev, I., Bhakdi, S. C., Hofmann, F., Djonder, N., Valeva, A., Aktories, K. and Bhakdi, S. (2001) Delivery of proteins into living cells by reversible membrane permeabilization with streptolysin-O. Proc. Natl. Acad. Sci. USA 98, $3185-$ 3190.

27 Collier, R. J. (1990) Diphtheria toxin: Structure and function of a cytocidal protein. In: ADP-Ribosylating Toxins and G Proteins: Insights into Signal Transduction, pp. 3-19, Moss, J. and Vaughan, M. (eds.), American Society of Microbiology, Washington D.C

28 Petosa, C., Collier, R. J., Klimpel, K. R., Leppla, S. H. and Liddington, R. C. (1997) Crystal structure of the anthrax toxin protective antigen. Nature 385, 833-838.

29 Santelli, E., Bankston, L. A., Leppla, S. H. and Liddington, R. C. (2004) Crystal structure of a complex between anthrax toxin and its host cell receptor. Nature 430, 905-908

30 Milne, J. C., Furlong, D., Hanna, P. C., Wall, J. S. and Collier, R. J. (1994) Anthrax protective antigen forms oligomers during intoxication of mammalian cells. J. Biol. Chem. 269, 20607-20612

31 Abrami, L., Lindsay, M., Parton, R. G., Leppla, S. H. and van der Goot, F. G. (2004) Membrane insertion of anthrax protective antigen and cytoplasmic delivery of lethal factor occur at different stages of the endocytic pathway. J. Cell Biol. 166, 645-651.

32 Abrami, L., Reig, N. and van der Goot, F. G. (2005) Anthrax toxin: The long and winding road that leads to the kill. Trends Microbiol. 13, 72-78

33 Cornelis, G. R. (2006) The type III secretion injectisome. Nat Rev. Microbiol. 4, 811-825.

34 Galan, J. E. (2001) Salmonella interactions with host cells: Type III secretion at work. Annu. Rev. Cell Dev. Biol. 17, 53 86.

35 Fields, K. A., Plano, G. V. and Straley, S. C. (1994) A low-Ca ${ }^{2+}$ response (LCR) secretion (ysc) locus lies within the lcrB region of the LCR plasmid in Yersinia pestis. J. Bacteriol. 176, $569-579$.

36 Van Gijsegem, F., Gough, C., Zischek, C., Niqueux, E., Arlat, M., Genin, S., Barberis, P., German, S., Castello, P. and Boucher, C. (1995) The hrp gene locus of Pseudomonas solanacearum, which controls the production of a type III secretion system, encodes eight proteins related to components of the bacterial flagellar biogenesis complex. Mol. Microbiol. 15, 1095-1114.

37 Faudry, E., Job, V., Dessen, A., Attree, I. and Forge, V. (2007) Type III secretion system translocator has a molten globule conformation both in its free and chaperone-bound forms. FEBS J. 274, 3601-3610.

38 Barrows, B. D., Griffitts, J. S. and Aroian, R. V. (2006) Caenorhabditis elegans carbohydrates in bacterial toxin resistance. Methods Enzymol. 417, 340-358.

39 Scobie, H. M. and Young, J. A. (2005) Interactions between anthrax toxin receptors and protective antigen. Curr. Opin. Microbiol. 8, 106-112.

40 Nelson, K. L., Raja, S. M. and Buckley, J. T. (1997) The glycosylphosphatidylinositol-anchored surface glycoprotein Thy- 1 is a receptor for the channel-forming toxin aerolysin. J. Biol. Chem. 272, 12170-12174.

41 Tweten, R. K., Parker, M. W. and Johnson, A. E. (2001) The cholesterol-dependent cytolysins. Curr. Top. Microbiol. Immunol. 257, 15-33.

42 Valeva, A., Hellmann, N., Walev, I., Strand, D., Plate, M., Boukhallouk, F., Brack, A., Hanada, K., Decker, H. and Bhakdi, S. (2006) Evidence that clustered phosphocholine head groups serve as sites for binding and assembly of an oligomeric protein pore. J. Biol. Chem. 281, 26014-26021.

43 Abrami, L. and van Der Goot, F. G. (1999) Plasma membrane microdomains act as concentration platforms to facilitate intoxication by aerolysin. J. Cell Biol. 147, 175-184.

44 Lafont, F., Abrami, L. and van der Goot, F. G. (2004) Bacterial subversion of lipid rafts. Curr. Opin. Microbiol. 7, 4-10.

45 Song, L., Hobaugh, M. R., Shustak, C., Cheley, S., Bayley, H. and Gouaux, J. E. (1996) Structure of staphylococcal alphahemolysin, a heptameric transmembrane pore. Science 274, 1859-1866.

46 Valeva, A., Pongs, J., Bhakdi, S. and Palmer, M. (1997) Staphylococcal alpha-toxin: The role of the N-terminus in formation of the heptameric pore - A fluorescence study. Biochim. Biophys. Acta 1325, 281-286.

47 Gurcel, L., Iacovache, I. and van der Goot, F. G. (2005) Aerolysin and related Aeromonas toxins. In: The Comprehensive Sourcebook of Bacterial Protein Toxins, Alouf, J. E. and Freer, J. H. (eds.), Academic Press, London.

48 Howard, S. P. and Buckley, J. T. (1985) Protein export by a gram-negative bacterium: Production of aerolysin by Aeromonas hydrophila. J. Bacteriol. 161, 1118-1124.

49 Hardie, K. R., Schulze, A., Parker, M. W. and Buckley, J. T. (1995) Vibrio spp. secrete proaerolysin as a folded dimer without the need for disulphide bond formation. Mol. Microbiol. 17, 1035-1044.

50 Howard, S. P., Critch, J. and Bedi, A. (1993) Isolation and analysis of eight exe genes and their involvement in extracellular protein secretion and outer membrane assembly in Aeromonas hydrophila. J. Bacteriol. 175, 6695-6703.

51 Jiang, B. and Howard, S. P. (1992) The Aeromonas hydrophila exeE gene, required both for protein secretion and normal outer membrane biogenesis, is a member of a general secretion pathway. Mol. Microbiol. 6, 1351-1361.

52 Abrami, L., Fivaz, M., Glauser, P. E., Parton, R. G. and van der Goot, F. G. (1998) A pore-forming toxin interacts with a GPI-anchored protein and causes vacuolation of the endoplasmic reticulum. J. Cell Biol. 140, 525-540.

53 Cowell, S., Aschauer, W., Gruber, H. J., Nelson, K. L. and Buckley, J. T. (1997) The erythrocyte receptor for the channelforming toxin aerolysin is a novel glycosylphosphatidylinositol-anchored protein. Mol. Microbiol. 25, 343-350.

54 Diep, D. B., Nelson, K. L., Raja, S. M., Pleshak, E. N. and Buckley, J. T. (1998) Glycosylphosphatidylinositol anchors of membrane glycoproteins are binding determinants for the channel-forming toxin aerolysin. J. Biol. Chem. 273, 23552360. 
55 Barry, R., Moore, S., Alonso, A., Ausio, J. and Buckley, J. T. (2001) The channel-forming protein proaerolysin remains a dimer at low concentrations in solution. J. Biol. Chem. 276, $551-554$.

56 van der Goot, F. G., Ausio, J., Wong, K. R., Pattus, F. and Buckley, J. T. (1993) Dimerization stabilizes the pore-forming toxin aerolysin in solution. J. Biol. Chem. 268, 18272-9.

57 Fivaz, M., Velluz, M. C. and van der Goot, F. G. (1999) Dimer dissociation of the pore-forming toxin aerolysin precedes receptor binding. J. Biol. Chem. 274, 37705-37708.

58 Parker, M. W., Buckley, J. T., Postma, J. P., Tucker, A. D., Leonard, K., Pattus, F. and Tsernoglou, D. (1994) Structure of the Aeromonas toxin proaerolysin in its water-soluble and membrane-channel states. Nature 367, 292-295.

59 Gordon, V. M., Nelson, K. L., Buckley, J. T., Stevens, V. L., Tweten, R. K., Elwood, P. C. and Leppla, S. H. (1999) Clostridium septicum alpha toxin uses glycosylphosphatidylinositol-anchored protein receptors. J. Biol. Chem. 274, 27274-27280.

60 Abrami, L., Velluz, M. C., Hong, Y., Ohishi, K., Mehlert, A., Ferguson, M., Kinoshita, T. and Gisou van der Goot, F. (2002) The glycan core of GPI-anchored proteins modulates aerolysin binding but is not sufficient: The polypeptide moiety is required for the toxin-receptor interaction. FEBS Lett. 512, 249-254.

61 Hong, Y., Ohishi, K., Inoue, N., Kang, J. Y., Shime, H., Horiguchi, Y., van der Goot, F. G., Sugimoto, N. and Kinoshita, T. (2002) Requirement of N-glycan on GPIanchored proteins for efficient binding of aerolysin but not Clostridium septicum alpha-toxin. EMBO J. 21, 5047-5056.

62 Fivaz, M., Vilbois, F., Thurnheer, S., Pasquali, C., Abrami, L., Bickel, P. E., Parton, R. G. and van der Goot, F. G. (2002) Differential sorting and fate of endocytosed GPI-anchored proteins. EMBO J. 21, 3989-4000.

63 Buckley, J. T., Wilmsen, H. U., Lesieur, C., Schulze, A., Pattus, F., Parker, M. W. and van der Goot, F. G. (1995) Protonation of histidine-132 promotes oligomerization of the channel-forming toxin aerolysin. Biochemistry 34, 1645016455.

64 Lesieur, C., Vecsey-Semjen, B., Abrami, L., Fivaz, M. and Gisou van der Goot, F. (1997) Membrane insertion: The strategies of toxins. Mol. Membr. Biol. 14, 45-64.

65 Ballard, J., Crabtree, J., Roe, B. A. and Tweten, R. K. (1995) The primary structure of Clostridium septicum alpha-toxin exhibits similarity with that of Aeromonas hydrophila aerolysin. Infect. Immun. 63, 340-344.

66 Bayley, H. (1994) Triggers and switches in a self-assembling pore-forming protein. J. Cell Biochem. 56, 177-182.

67 Bhakdi, S. and Tranum-Jensen, J. (1991) Alpha-toxin of Staphylococcus aureus. Microbiol. Rev. 55, 733-751.

68 Walker, B., Braha, O., Cheley, S. and Bayley, H. (1995) An intermediate in the assembly of a pore-forming protein trapped with a genetically-engineered switch. Chem. Biol. 2, 99-105.

69 Walker, B., Krishnasastry, M., Zorn, L. and Bayley, H. (1992) Assembly of the oligomeric membrane pore formed by Staphylococcal alpha-hemolysin examined by truncation mutagenesis. J. Biol. Chem. 267, 21782-21786.

70 Valeva, A., Palmer, M., Hilgert, K., Kehoe, M. and Bhakdi, S. (1995) Correct oligomerization is a prerequisite for insertion of the central molecular domain of staphylococcal alpha-toxin into the lipid bilayer. Biochim. Biophys. Acta 1236, 213-218.

71 Valeva, A., Weisser, A., Walker, B., Kehoe, M., Bayley, H., Bhakdi, S. and Palmer, M. (1996) Molecular architecture of a toxin pore: a 15-residue sequence lines the transmembrane channel of staphylococcal alpha-toxin. EMBO J. 15, $1857-$ 1864

72 Walker, B., Krishnasastry, M. and Bayley, H. (1993) Functional complementation of staphylococcal alpha-hemolysin fragments. Overlaps, nicks, and gaps in the glycine-rich loop. J. Biol. Chem. 268, 5285-5292.
73 Ward, R. J., Palmer, M., Leonard, K. and Bhakdi, S. (1994) Identification of a putative membrane-inserted segment in the alpha-toxin of Staphylococcus aureus. Biochemistry 33, $7477-7484$

74 Tweten, R. K. (2005) Cholesterol-dependent cytolysins, a family of versatile pore-forming toxins. Infect. Immun. 73, 6199-6209.

75 Madden, J. C., Ruiz, N. and Caparon, M. (2001) Cytolysinmediated translocation (CMT): A functional equivalent of type III secretion in gram-positive bacteria. Cell 104, 143152.

76 Bavdek, A., Gekara, N. O., Priselac, D., Gutierrez Aguirre, I., Darji, A., Chakraborty, T., Macek, P., Lakey, J. H., Weiss, S. and Anderluh, G. (2007) Sterol and $\mathrm{pH}$ interdependence in the binding, oligomerization, and pore formation of Listeriolysin O. Biochemistry 46, 4425-4437.

77 Moors, M. A., Levitt, B., Youngman, P. and Portnoy, D. A. (1999) Expression of listeriolysin O and ActA by intracellular and extracellular Listeria monocytogenes. Infect. Immun. 67, $131-139$.

78 Walker, J. A., Allen, R. L., Falmagne, P., Johnson, M. K. and Boulnois, G. J. (1987) Molecular cloning, characterization, and complete nucleotide sequence of the gene for pneumolysin, the sulfhydryl-activated toxin of Streptococcus pneumoniae. Infect. Immun. 55, 1184-1189.

79 Iwamoto, M., Ohno-Iwashita, Y. and Ando, S. (1987) Role of the essential thiol group in the thiol-activated cytolysin from Clostridium perfringens. Eur. J. Biochem. 167, 425-430.

80 Sekino-Suzuki, N., Nakamura, M., Mitsui, K. I. and OhnoIwashita, Y. (1996) Contribution of individual tryptophan residues to the structure and activity of theta-toxin (perfringolysin O), a cholesterol-binding cytolysin. Eur. J. Biochem. 241, 941-947.

81 Jacobs, T., Darji, A., Frahm, N., Rohde, M., Wehland, J., Chakraborty, T. and Weiss, S. (1998) Listeriolysin O: Cholesterol inhibits cytolysis but not binding to cellular membranes. Mol. Microbiol. 28, 1081-1089.

82 Johnson, M. K., Geoffroy, C. and Alouf, J. E. (1980) Binding of cholesterol by sulfhydryl-activated cytolysins. Infect. Immun. 27, 97-101.

83 Giddings, K. S., Zhao, J., Sims, P. J. and Tweten, R. K. (2004) Human CD59 is a receptor for the cholesterol-dependent cytolysin intermedilysin. Nat. Struct. Mol. Biol. 11, 11731178.

84 Polekhina, G., Giddings, K. S., Tweten, R. K. and Parker, M. W. (2005) Insights into the action of the superfamily of cholesterol-dependent cytolysins from studies of intermedilysin. Proc. Natl. Acad. Sci. USA 102, 600-605.

85 Giddings, K. S., Johnson, A. E. and Tweten, R. K. (2003) Redefining cholesterol's role in the mechanism of the cholesterol-dependent cytolysins. Proc. Natl. Acad. Sci. USA 100,11315-11320.

86 Shimada, Y., Maruya, M., Iwashita, S. and Ohno-Iwashita, Y. (2002) The C-terminal domain of perfringolysin $\mathrm{O}$ is an essential cholesterol-binding unit targeting to cholesterol-rich microdomains. Eur. J. Biochem. 269, 6195-6203.

87 Waheed, A. A., Shimada, Y., Heijnen, H. F., Nakamura, M., Inomata, M., Hayashi, M., Iwashita, S., Slot, J. W. and OhnoIwashita, Y. (2001) Selective binding of perfringolysin O derivative to cholesterol-rich membrane microdomains (rafts). Proc. Natl. Acad. Sci. USA 98, 4926-4931.

88 Gekara, N. O., Jacobs, T., Chakraborty, T. and Weiss, S. (2005) The cholesterol-dependent cytolysin listeriolysin $\mathrm{O}$ aggregates rafts via oligomerization. Cell. Microbiol. 7,1345-1356.

89 Gekara, N. O. and Weiss, S. (2004) Lipid rafts clustering and signalling by listeriolysin O. Biochem. Soc. Trans. 32, 712714.

90 Tilley, S. J., Orlova, E. V., Gilbert, R. J., Andrew, P. W. and Saibil, H. R. (2005) Structural basis of pore formation by the bacterial toxin pneumolysin. Cell 121, 247-256.

91 Shepard, L. A., Shatursky, O., Johnson, A. E. and Tweten, R. K. (2000) The mechanism of pore assembly for a choles- 
terol-dependent cytolysin: Formation of a large prepore complex precedes the insertion of the transmembrane betahairpins. Biochemistry 39, 10284-10293.

92 Heuck, A. P., Tweten, R. K. and Johnson, A. E. (2003) Assembly and topography of the prepore complex in cholesterol-dependent cytolysins. J. Biol. Chem. 278, 31218-31225.

93 Gilbert, R. J. (2002) Pore-forming toxins. Cell. Mol. Life Sci. 59, 832-844.

94 Palmer, M., Harris, R., Freytag, C., Kehoe, M., TranumJensen, J. and Bhakdi, S. (1998) Assembly mechanism of the oligomeric streptolysin O pore: The early membrane lesion is lined by a free edge of the lipid membrane and is extended gradually during oligomerization. EMBO J. 17, 1598-1605.

95 Collier, R. J. and Young, J. A. (2003) Anthrax toxin. Annu. Rev. Cell Dev. Biol. 19, 45-70.

96 Bradley, K. A., Mogridge, J., Mourez, M., Collier, R. J. and Young, J. A. (2001) Identification of the cellular receptor for anthrax toxin. Nature 414, 225-229.

97 Scobie, H. M., Rainey, G. J., Bradley, K. A. and Young, J. A. (2003) Human capillary morphogenesis protein 2 functions as an anthrax toxin receptor. Proc. Natl. Acad. Sci. USA 100, $5170-5174$.

98 Gordon, V. M., Klimpel, K. R., Arora, N., Henderson, M. A. and Leppla, S. H. (1995) Proteolytic activation of bacterial toxins by eukaryotic cells is performed by furin and by additional cellular proteases. Infect. Immun. 63, 82-87.

99 Milne, J. C. and Collier, R. J. (1993) pH-dependent permeabilization of the plasma membrane of mammalian cells by anthrax protective antigen. Mol. Microbiol. 10, 647-653.

100 Lacy, D. B., Lin, H. C., Melnyk, R. A., Schueler-Furman, O., Reither, L., Cunningham, K., Baker, D. and Collier, R. J. (2005) A model of anthrax toxin lethal factor bound to protective antigen. Proc. Natl. Acad. Sci. USA 102, 16409 16414.

101 Rainey, G. J., Wigelsworth, D. J., Ryan, P. L., Scobie, H. M., Collier, R. J. and Young, J. A. (2005) Receptor-specific requirements for anthrax toxin delivery into cells. Proc. Natl. Acad. Sci. USA 102, 13278-13283.

102 Lacy, D. B., Wigelsworth, D. J., Melnyk, R. A., Harrison, S. C. and Collier, R. J. (2004) Structure of heptameric protective antigen bound to an anthrax toxin receptor: A role for receptor in $\mathrm{pH}$-dependent pore formation. Proc. Natl. Acad. Sci. USA 101, 13147-13151.

103 Abrami, L., Liu, S., Cosson, P., Leppla, S. H. and van der Goot, F. G. (2003) Anthrax toxin triggers endocytosis of its receptor via a lipid raft-mediated clathrin-dependent process. J. Cell Biol. 160, 321-328.

104 Blaustein, R. O., Koehler, T. M., Collier, R. J. and Finkelstein, A. (1989) Anthrax toxin: Channel-forming activity of protective antigen in planar phospholipid bilayers. Proc. Natl. Acad. Sci. USA 86, 2209-2213.

105 Krantz, B. A., Trivedi, A. D., Cunningham, K., Christensen, K. A. and Collier, R. J. (2004) Acid-induced unfolding of the amino-terminal domains of the lethal and edema factors of anthrax toxin. J. Mol. Biol. 344, 739-756.

106 Wesche, J., Elliott, J. L., Falnes, P. O., Olsnes, S. and Collier, R. J. (1998) Characterization of membrane translocation by anthrax protective antigen. Biochemistry 37, 15737-15746.

107 Ogawa, M., Yoshimori, T., Suzuki, T., Sagara, H., Mizushima, N. and Sasakawa, C. (2005) Escape of intracellular Shigella from autophagy. Science 307, 727-731.

108 Ernst, J. D. (2000) Bacterial inhibition of phagocytosis. Cell. Microbiol. 2, 379-386.

109 Hernandez, L. D., Hueffer, K., Wenk, M. R. and Galan, J. E. (2004) Salmonella modulates vesicular traffic by altering phosphoinositide metabolism. Science 304, 1805-1807.

110 Cornelis, G. R. (2002) The Yersinia Ysc-Yop 'type III' weaponry. Nat. Rev. Mol. Cell. Biol. 3, 742-752.

111 Troisfontaines, P. and Cornelis, G. R. (2005) Type III secretion: More systems than you think. Physiology (Bethesda) 20, 326-339.
112 Cossart, P. and Sansonetti, P. J. (2004) Bacterial invasion: The paradigms of enteroinvasive pathogens. Science 304, 242 248.

113 Cossart, P. and Lecuit, M. (1998) Interactions of Listeria monocytogenes with mammalian cells during entry and actinbased movement: bacterial factors, cellular ligands and signaling. EMBO J. 17, 3797-3806.

114 Kayal, S., Lilienbaum, A., Poyart, C., Memet, S., Israel, A. and Berche, P. (1999) Listeriolysin O-dependent activation of endothelial cells during infection with Listeria monocytogenes: Activation of NF-kappa B and upregulation of adhesion molecules and chemokines. Mol. Microbiol. 31, 1709-1722.

115 Hamon, M. A., Batsche, E., Regnault, B., Tham, T. N., Seveau, S., Muchardt, C. and Cossart, P. (2007) Histone modifications induced by a family of bacterial toxins. Proc. Natl. Acad. Sci. USA 104, 13467-13472.

116 Repp, H., Pamukci, Z., Koschinski, A., Domann, E., Darji, A., Birringer, J., Brockmeier, D., Chakraborty, T. and Dreyer, F. (2002) Listeriolysin of Listeria monocytogenes forms $\mathrm{Ca}^{2+}$ permeable pores leading to intracellular $\mathrm{Ca}^{2+}$ oscillations. Cell. Microbiol. 4, 483-491.

117 Uhlen, P., Laestadius, A., Jahnukainen, T., Soderblom, T., Backhed, F., Celsi, G., Brismar, H., Normark, S., Aperia, A. and Richter-Dahlfors, A. (2000) Alpha-haemolysin of uropathogenic E. coli induces $\mathrm{Ca}^{2+}$ oscillations in renal epithelial cells. Nature 405, 694-697.

118 Koschinski, A., Repp, H., Unver, B., Dreyer, F., Brockmeier, D., Valeva, A., Bhakdi, S. and Walev, I. (2006) Why Escherichia coli alpha-hemolysin induces calcium oscillations in mammalian cells - The pore is on its own. FASEB J. 20, 973-975.

119 Lewis, R. S. (2003) Calcium oscillations in T-cells: Mechanisms and consequences for gene expression. Biochem. Soc. Trans. 31, 925-929.

120 Berridge, M. J., Bootman, M. D. and Roderick, H. L. (2003) Calcium signalling: Dynamics, homeostasis and remodelling. Nat. Rev. Mol. Cell. Biol. 4, 517-529.

121 Dramsi, S. and Cossart, P. (2003) Listeriolysin O-mediated calcium influx potentiates entry of Listeria monocytogenes into the human Hep-2 epithelial cell line. Infect. Immun. 71, 3614-3618.

122 Gekara, N. O., Westphal, K., Ma, B., Rohde, M., Groebe, L. and Weiss, S. (2007) The multiple mechanisms of $\mathrm{Ca}(2+)$ signalling by listeriolysin $\mathrm{O}$, the cholesterol-dependent cytolysin of Listeria monocytogenes. Cell. Microbiol. 9, 20082021.

123 Iliev, A. I., Djannatian, J. R., Nau, R., Mitchell, T. J. and Wouters, F. S. (2007) Cholesterol-dependent actin remodeling via RhoA and Rac1 activation by the Streptococcus pneumoniae toxin pneumolysin. Proc. Natl. Acad. Sci. USA 104, 2897-2902.

124 Berry, A. M., Yother, J., Briles, D. E., Hansman, D. and Paton, J. C. (1989) Reduced virulence of a defined pneumolysin-negative mutant of Streptococcus pneumoniae. Infect. Immun. 57, 2037-2042.

125 Paton, J. C., Andrew, P. W., Boulnois, G. J. and Mitchell, T. J. (1993) Molecular analysis of the pathogenicity of Streptococcus pneumoniae: The role of pneumococcal proteins. Annu. Rev. Microbiol. 47, 89-115.

126 Paton, J. C., Berry, A. M., Lock, R. A., Hansman, D. and Manning, P. A. (1986) Cloning and expression in Escherichia coli of the Streptococcus pneumoniae gene encoding pneumolysin. Infect. Immun. 54, 50-55.

127 Paton, J. C., Lock, R. A. and Hansman, D. J. (1983) Effect of immunization with pneumolysin on survival time of mice challenged with Streptococcus pneumoniae. Infect. Immun. 40, 548-552.

128 Hirst, R. A., Kadioglu, A., O'Callaghan, C. and Andrew, P.W. (2004) The role of pneumolysin in pneumococcal pneumonia and meningitis. Clin. Exp. Immunol. 138, 195201. 
129 Rayner, C. F., Jackson, A. D., Rutman, A., Dewar, A. Mitchell, T. J., Andrew, P. W., Cole, P. J. and Wilson, R. (1995) Interaction of pneumolysin-sufficient and-deficient isogenic variants of Streptococcus pneumoniae with human respiratory mucosa. Infect. Immun. 63, 442-447.

130 Steinfort, C., Wilson, R., Mitchell, T., Feldman, C., Rutman, A., Todd, H., Sykes, D., Walker, J., Saunders, K., Andrew, P. W., Boulnois, G. J. and Cole, P. J. (1989) Effect of Streptococcus pneumoniae on human respiratory epithelium in vitro. Infect. Immun. 57, 2006-2013.

131 Akira, S., Uematsu, S. and Takeuchi, O. (2006) Pathogen recognition and innate immunity. Cell 124, 783-801.

132 Medzhitov, R. (2001) Toll-like receptors and innate immunity. Nat. Rev. Immunol. 1, 135-145.

133 Martinon, F. and Tschopp, J. (2005) NLRs join TLRs as innate sensors of pathogens. Trends Immunol. 26, 447-454.

134 Gurcel, L., Abrami, L., Girardin, S., Tschopp, J. and van der Goot, F. G. (2006) Caspase-1 activation of lipid metabolic pathways in response to bacterial pore-forming toxins promotes cell survival. Cell 126, 1135-1145.

135 Walev, I., Reske, K., Palmer, M., Valeva, A. and Bhakdi, S. (1995) Potassium-inhibited processing of IL-1 beta in human monocytes. EMBO J. 14, 1607-1614.

136 Franchi, L., Amer, A., Body-Malapel, M., Kanneganti, T. D., Ozoren, N., Jagirdar, R., Inohara, N., Vandenabeele, P. Bertin, J., Coyle, A., Grant, E. P. and Nunez, G. (2006) Cytosolic flagellin requires Ipaf for activation of caspase-1 and interleukin 1beta in salmonella-infected macrophages. Nat. Immunol. 7, 576-582.

137 Bonizzi, G. and Karin, M. (2004) The two NF-kappaB activation pathways and their role in innate and adaptive immunity. Trends Immunol. 25, 280-288.

138 Dragneva, Y., Anuradha, C. D., Valeva, A., Hoffmann, A. Bhakdi, S. and Husmann, M. (2001) Subcytocidal attack by staphylococcal alpha-toxin activates NF-kappaB and induces interleukin-8 production. Infect. Immun. 69, 2630-2635.

139 Chopra, A. K., Xu, X., Ribardo, D., Gonzalez, M., Kuhl, K., Peterson, J. W. and Houston, C. W. (2000) The cytotoxic enterotoxin of Aeromonas hydrophila induces proinflammatory cytokine production and activates arachidonic acid metabolism in macrophages. Infect. Immun. 68, 2808-2818.

140 Fickl, H., Cockeran, R., Steel, H. C., Feldman, C., Cowan, G., Mitchell, T. J. and Anderson, R. (2005) Pneumolysin-mediated activation of NFkappaB in human neutrophils is antagonized by docosahexaenoic acid. Clin. Exp. Immunol. 140, 274-281.

141 Kayal, S., Lilienbaum, A., Join-Lambert, O., Li, X., Israel, A. and Berche, P. (2002) Listeriolysin O secreted by Listeria monocytogenes induces NF-kappaB signalling by activating the IkappaB kinase complex. Mol. Microbiol. 44, 1407-1419.

142 Martinon, F., Burns, K. and Tschopp, J. (2002) The inflammasome: A molecular platform triggering activation of inflammatory caspases and processing of proIL-beta. Mol. Cell 10, 417-426.

143 Dinarello, C. A. (1998) Interleukin-1 beta, interleukin-18, and the interleukin-1 beta converting enzyme. Ann. N. Y. Acad. Sci. 856, 1-11.

144 Mariathasan, S., Weiss, D. S., Newton, K., McBride, J., O'Rourke, K., Roose-Girma, M., Lee, W. P., Weinrauch, Y. Monack, D. M. and Dixit, V. M. (2006) Cryopyrin activates the inflammasome in response to toxins and ATP. Nature 440 $228-232$

145 Ozoren, N., Masumoto, J., Franchi, L., Kanneganti, T. D., Body-Malapel, M., Erturk, I., Jagirdar, R., Zhu, L., Inohara, N., Bertin, J., Coyle, A., Grant, E. P. and Nunez, G. (2006) Distinct roles of TLR2 and the adaptor ASC in IL-1beta/IL18 secretion in response to Listeria monocytogenes. J. Immunol. 176, 4337-4342.

146 Cordoba-Rodriguez, R., Fang, H., Lankford, C. S. and Frucht, D. M. (2004) Anthrax lethal toxin rapidly activates caspase-1/ ICE and induces extracellular release of interleukin (IL)1beta and IL-18. J. Biol. Chem. 279, 20563-20566.
147 Boyden, E. D. and Dietrich, W. F. (2006) Nalp1b controls mouse macrophage susceptibility to anthrax lethal toxin. Nat. Genet. 38, 240-244.

148 Wickliffe, K. E., Leppla, S. H. and Moayeri, M. (2007) Anthrax lethal toxin-induced inflammasome formation and caspase-1 activation are late events dependent on ion fluxes and the proteasome. Cell Microbiol (in press).

149 Ren, T., Zamboni, D. S., Roy, C. R., Dietrich, W. F. and Vance, R. E. (2006) Flagellin-deficient Legionella mutants evade caspase-1- and Naip5-mediated macrophage immunity. PLoS Pathog. 2, e18.

150 Miao, E. A., Alpuche-Aranda, C. M., Dors, M., Clark, A. E., Bader, M. W., Miller, S. I. and Aderem, A. (2006) Cytoplasmic flagellin activates caspase-1 and secretion of interleukin 1beta via Ipaf. Nat. Immunol. 7, 569-575.

151 Zamboni, D. S., Kobayashi, K. S., Kohlsdorf, T., Ogura, Y., Long, E. M., Vance, R. E., Kuida, K., Mariathasan, S., Dixit, V. M., Flavell, R. A., Dietrich, W. F. and Roy, C. R. (2006) The Birc1e cytosolic pattern-recognition receptor contributes to the detection and control of Legionella pneumophila infection. Nat. Immunol. 7, 318-325.

152 Shin, H. and Cornelis, G. R. (2007) Type III secretion translocation pores of Yersinia enterocolitica trigger maturation and release of Pro-inflammatory IL-1beta. Cell. Microbiol. (in press).

153 Goldstein, J. L., DeBose-Boyd, R. A. and Brown, M. S. (2006) Protein sensors for membrane sterols. Cell 124, 35-46.

154 Huffman, D. L., Abrami, L., Sasik, R., Corbeil, J., van der Goot, F. G. and Aroian, R. V. (2004) Mitogen-activated protein kinase pathways defend against bacterial pore-forming toxins. Proc. Natl. Acad. Sci. USA 101, 10995-11000.

155 Kim, D. H., Feinbaum, R., Alloing, G., Emerson, F. E., Garsin, D. A., Inoue, H., Tanaka-Hino, M., Hisamoto, N., Matsumoto, K., Tan, M. W. and Ausubel, F. M. (2002) A conserved p38 MAP kinase pathway in Caenorhabditis elegans innate immunity. Science 297, 623-626.

156 Husmann, M., Dersch, K., Bobkiewicz, W., Beckmann, E., Veerachato, G. and Bhakdi, S. (2006) Differential role of p38 mitogen activated protein kinase for cellular recovery from attack by pore-forming $S$. aureus alpha-toxin or streptolysin O. Biochem. Biophys. Res. Commun. 344, 1128-1134.

157 Ratner, A. J., Hippe, K. R., Aguilar, J. L., Bender, M. H., Nelson, A. L. and Weiser, J. N. (2006) Epithelial cells are sensitive detectors of bacterial pore-forming toxins. J. Biol. Chem. 281, 12994-12998.

158 Stassen, M., Muller, C., Richter, C., Neudorfl, C., Hultner, L., Bhakdi, S., Walev, I. and Schmitt, E. (2003) The streptococcal exotoxin streptolysin $\mathrm{O}$ activates mast cells to produce tumor necrosis factor alpha by $\mathrm{p} 38$ mitogen-activated protein kinase- and protein kinase C-dependent pathways. Infect. Immun. 71, 6171-6177.

159 Stringaris, A. K., Geisenhainer, J., Bergmann, F., Balshusemann, C., Lee, U., Zysk, G., Mitchell, T. J., Keller, B. U., Kuhnt, U., Gerber, J., Spreer, A., Bahr, M., Michel, U. and Nau, R. (2002) Neurotoxicity of pneumolysin, a major pneumococcal virulence factor, involves calcium influx and depends on activation of $\mathrm{p} 38$ mitogen-activated protein kinase. Neurobiol. Dis. 11, 355-368.

160 Haugwitz, U., Bobkiewicz, W., Han, S. R., Beckmann, E., Veerachato, G., Shaid, S., Biehl, S., Dersch, K., Bhakdi, S. and Husmann, M. (2006) Pore-forming Staphylococcus aureusalpha-toxin triggers epidermal growth factor receptor-dependent proliferation. Cell. Microbiol. 8, 1591-1600.

161 Gutierrez, M. G., Saka, H. A., Chinen, I., Zoppino, F. C., Yoshimori, T., Bocco, J. L. and Colombo, M. I. (2007) Protective role of autophagy against Vibrio cholerae cytolysin, a pore-forming toxin from V. cholerae. Proc. Natl. Acad. Sci. USA 104, 1829-1834.

162 Gutierrez, M. G., Master, S. S., Singh, S. B., Taylor, G. A., Colombo, M. I. and Deretic, V. (2004) Autophagy is a defense mechanism inhibiting BCG and Mycobacterium tuberculosis survival in infected macrophages. Cell 119, 753-766. 
163 Nakagawa, I., Amano, A., Mizushima, N., Yamamoto, A., Yamaguchi, H., Kamimoto, T., Nara, A., Funao, J., Nakata, M., Tsuda, K., Hamada, S. and Yoshimori, T. (2004) Autophagy defends cells against invading group A Streptococcus. Science 306, 1037-1040.

164 Suzuki, T., Franchi, L., Toma, C., Ashida, H., Ogawa, M., Yoshikawa, Y., Mimuro, H., Inohara, N., Sasakawa, C. and Nunez, G. (2007) Differential regulation of caspase-1 activation, pyroptosis, and autophagy via Ipaf and ASC in Shigellainfected macrophages. PLoS Pathog. 3, e111.

165 Walev, I., Palmer, M., Martin, E., Jonas, D., Weller, U., HohnBentz, H., Husmann, M. and Bhakdi, S. (1994) Recovery of human fibroblasts from attack by the pore-forming alphatoxin of Staphylococcus aureus. Microb. Pathog. 17, 187-201.

166 McNeil, P. L. and Steinhardt, R. A. (2003) Plasma membrane disruption: Repair, prevention, adaptation. Annu. Rev. Cell Dev. Biol. 19, 697-731.

167 Lesieur, C., Frutiger, S., Hughes, G., Kellner, R., Pattus, F. and van Der Goot, F. G. (1999) Increased stability upon heptamerization of the pore-forming toxin aerolysin. J. Biol. Chem. 274, 36722-36728.

168 Griffitts, J. S., Haslam, S. M., Yang, T., Garczynski, S. F., Mulloy, B., Morris, H., Cremer, P. S., Dell, A., Adang, M. J. and Aroian, R. V. (2005) Glycolipids as receptors for Bacillus thuringiensis crystal toxin. Science 307, 922-925.

169 Duncan, J. L. and Schlegel, R. (1975) Effect of streptolysin O on erythrocyte membranes, liposomes, and lipid dispersions. A protein-cholesterol interaction. J. Cell Biol. 67, 160-174.

170 Naglich, J. G., Metherall, J. E., Russell, D. W. and Eidels, L. (1992) Expression cloning of a diphtheria toxin receptor: Identity with a heparin-binding EGF-like growth factor precursor. Cell 69, 1051-1061.

171 Saha, N. and Banerjee, K. K. (1997) Carbohydrate-mediated regulation of interaction of Vibrio cholerae hemolysin with erythrocyte and phospholipid vesicle. J. Biol. Chem. 272, $162-167$.

\section{To access this journal online: http://www.birkhauser.ch/CMLS}

